C.R. Schenk, 'Parasitic invasions’ or sources of good governance: constraining foreign competition in Hong Kong banking, 1956-81'.

Published in Business History, vol. 51, No. 2, March 2009, 157-179.

The 1960s and 1970s were decades of tremendous expansion in international banking and financial activity through the expansion of international networks, particularly by US banks, and by product innovations designed to cope with exchange rate and interest rate instability and to evade regulation. While London continued to dominate as the major international financial centre with New York closely behind, other IFCs emerged or re-emerged in this new and challenging environment. These developments posed significant challenges for regulators who sought on the one hand to promote financial activity, but on the other hand hoped to limit the exposure of their banking systems to the instability of the international monetary and financial system. Many established economies like France, the USA, Japan and Australia sided with protection and curbed the penetration of foreign banks while a few others, such as the UK and centres in the Caribbean, welcomed the increased business they provided. ${ }^{1} \quad$ In the case of London regulators promoted offshore business while retaining exchange controls on residents. This paper explores how the regulators of one emerging IFC coped with these challenges and moved from being captured by incumbent firms to adopting a more independent and liberal approach while still protecting the local retail market. The attitudes of the state and the incumbents conformed to the divergent views in the current economics literature on the impact of foreign bank penetration. The state hoped to gain the advantages described by Levine in terms of improved efficiency, management skills and technology through controlling market entry, while incumbents feared the outcome described by Claessens et. al. of falling profits and margins from increased competition. ${ }^{2}$ The case of Hong Kong is further of interest because of its huge success in exploiting its advantages of language, law and location to establish the most prominent IFC in Asia during this period despite continued controls on foreign banks. While it seemed reasonable for large European economies to protect their incumbents from foreign competition, the options were more finely balanced for the Hong Kong government faced with a small open economy more dependent on international financial activity.

By the 1970s, Hong Kong had emerged as a major regional and global international financial centre, particularly because of its strong representation in 
global banking. This reflected the rise of East Asian economic growth, restrictions elsewhere in the region on international banking (particularly Tokyo) and open exchange and trade markets. In the historiography of these developments, the IFC in Hong Kong is usually described as developing organically from the historical entrepot activities of the colony and commercial relations with China and then the wider East Asian region. ${ }^{3}$ The rise of Hong Kong as an international financial centre is usually attributed to the lack of government interference that provided a safe haven for regional capital. Henry Smith famously dubbed the colony 'John Stuart Mill’s Other Island' in recognition of the free markets that prevailed there. ${ }^{4}$ Milton Friedman consistently praised the laissez-faire economic policies of Hong Kong's Financial Secretary Sir John Cowperthwaite during the 1960s. Among Friedman’s final publications was a contribution to the Wall Street Journal where he described Hong Kong as 'a shining symbol of economic freedom'. ${ }^{5}$ In 1998, Friedman specifically attributed the relatively poor economic growth of Britain compared to Hong Kong to 'socialism in Britain, free enterprise and free markets in Hong Kong. ${ }^{6}$ This characterisation is certainly true for international capital flows and the foreign exchange market, which operated more freely than almost any other centre in the world in the 1950s. ${ }^{7} \quad$ The low tax structure attracted business and capital to the colony and reflected the official policy of 'positive non-interventionism' at a time when most governments, particularly the imperial metropole Britain, were highly interventionist. In this context, the rise of Hong Kong as an IFC is generally regarded as uncontested. Nevertheless regulations on entry into the banking system from 1965 and a cartel for deposit interest rates from 1964 until 2001 constrained free competition. The banking sector, a core element in the development of the economy and the international financial centre, was certainly not a free market during the glorious 'half-century of positive non-interventionism' described by Friedman. Indeed, Hong Kong arguably developed as a major regional financial centre in the 1960s and 1970s despite of rather than because of the regulatory framework that operated in the colony.

In 1964, in response to a supposed 'interest rate war' the Exchange Banks Association (the precursor to the Hong Kong Association of Banks) negotiated an Interest Rate Agreement that applied to all banks operating in the colony to restrict price competition for deposits. Interest rate cartels were not unusual in the 1960s; similar arrangements existed in both the USA and the UK. However, these countries 
abandoned interest rate controls in the 1970s, while Hong Kong maintained their Interest Rate Rules in amended form until 2001. Secondly and more unusually, in May 1965, after two waves of banking crisis in February and April of that year, the government imposed a moratorium on all new bank licenses (foreign and domestic) to contain what was viewed as excessive competition. ${ }^{8}$ Once the moratorium was lifted in 1978 it continued to discriminate against foreign banks by limiting them to one office to contain competition in the local retail market. The Hong Kong government finally lifted barriers to entry of foreign banks in 2001.

The official rationale for the moratorium on new bank licenses in 1965 was to enhance stability by encouraging consolidation in the banking sector. Forty years later, the relationship between stability of banking systems and concentration is still the subject of debate. ${ }^{9} \quad$ On the one hand a comparison between the historically unstable US system, with a proliferation of small banks, and the relatively stable systems of Canada and Europe, where a few large banks dominate, suggests that 'big is beautiful'. Large banks might be better able to diversify risk, and a less competitive environment might make banks less prone to engage in risky behaviour. Allen and Gale have also argued that it is easier for a government to supervise and enforce prudential supervision in a system with a small number of banks. ${ }^{10}$ On the other hand, the dominance of a few large banks might lead to a situation where they become 'too big to fail' and thus induce moral hazard. Large banks may also have complex and opaque operations that make supervision more challenging. International evidence has also suggested that systems where small banks have greater market share have more lending to SMEs. ${ }^{11}$

Recent empirical research suggests that barriers to entry by foreign banks do not enhance financial stability. ${ }^{12}$ Removing such barriers may increase the quality of the banking system through the import of managerial and technological efficiencies. Where banks are subject to sound regulatory and supervisory jurisdictions at home this may also transfer to the host centre, so prudential supervision might be imported. On the other hand, foreign banks may face more information obstacles when lending to local SMEs, an issue that could have had particular relevance for Hong Kong, where SMEs dominated the manufacturing sector. ${ }^{13}$ In a study of 80 developed and developing economies, Claessens et al found that increased foreign penetration reduces profits and margins for domestic banks particularly in developing economies, thus improving efficiency through competition, but challenging incumbent interests. ${ }^{14}$ 
This paper investigates the operation and impact of the moratorium on new banking licences: first by examining foreign banks' attempts to circumvent the moratorium through claims of special circumstances and buying interests in local banks, and secondly by examining the efforts of incumbents to extend barriers to non-bank financial institutions and to branches of foreign banks. The general conclusions are that while the moratorium was aimed at increasing the stability of the banking system, it had the effect of decreasing the regulatory breadth of the government, and reducing incentives for mergers and acquisitions that might have improved governance. Widespread evidence of fraud immediately after the moratorium ended show that it was not an effective cure for the governance problems of the Hong Kong banking system. The experience suggests that barriers to entry alone are not a substitute for effective prudential supervision nor an effective way to import good practice. The analysis also emphasizes the conflict between the government's support of the development of the IFC in Hong Kong and local banking interests, and how this was resolved through the regulatory system. Particularly evident is the high level of hostility even among the largest banks in Hong Kong to the entry of new foreign competition. By convincing the government that competition was dangerous for depositors, existing banks were able to maintain high barriers to entry for foreign banks and eventually to negotiate restrictions on the activities of non-bank financial institutions as well. Their main successes, however, were limited to the protection of the retail market because of the state's support of the international financial centre. The evidence provides greater detail to underpin the conclusions of Goodstadt and Greenwood that the regulatory framework for Hong Kong banking in the 1970s was inadequate and positively damaging to the stability of the system. ${ }^{15}$

\section{The Banking System in the 1960s}

There was no central bank in Hong Kong so the duties of note issue, prudential supervision, regulation and lending of last resort were shared between the government and commercial banks. Currency notes were issued by the HSBC, Chartered Bank and the Mercantile Bank under an effective currency board system operated through the government's Exchange Fund. There were no restrictions on international capital flows and so no distinction between off-shore and on-shore business. Offshore earnings were subject to a withholding tax that prevented the operation of the 
Asia-dollar market in Hong Kong, a privilege that went to Singapore. A Banking Advisory Committee (made up of the Financial Secretary, the Accountant General, bank representatives and an accountant) advised the government on issues related to the banking industry. The Exchange Banks Association, led by the HSBC, set the interest rates payable on deposits under the Interest Rate Agreement. The regulatory system was underdeveloped until 1965 when a more robust Banking Ordinance was introduced including monitoring of balance sheets and limits on insider lending. ${ }^{16}$ Institutions intending to accept deposits 'from the general public' could apply for a license to call themselves banks so long as they met minimum requirements of paid up capital. Disappointed applicants could appeal to the Governor but not the courts. A Banking Commissioner (Leo Cole until 1971, then JC Paterson) was appointed under the Ordinance, but his budget was small and his powers constrained by the Financial Secretary (Sir JJ Cowperthwaite until 1971, then Sir Philip Haddon-Cave). The change in the personalities of Financial Secretary and Banking Commissioner in 1971 prompted a shift in the attitude to the moratorium and we can mark its erosion from this date. Weaknesses in prudential supervision and enforcement continued, however, and contributed to the persistence of poor governance structures among many Hong Kong banks into the 1980s.

While poor governance in Asia was not unusual in the 1960s, since banks were often tied to business groups or the government, Hong Kong was distinctive because it was already emerging as an important regional and global financial centre. The number of banks increased sharply from the late 1950s due to increased domestic demand from the large immigrant population, growing industry in the colony, and also flight of capital to Hong Kong from elsewhere in Asia due to political and economic uncertainty in the region. This changing environment prompted two waves of local banking crisis: in 1961 and in 1965 . The causes of the banking crises are beyond the scope of this paper but they are well covered in existing literature. ${ }^{17}$ In summary, the diagnosis was that excessive competition was encouraging risky behaviour, that Hong Kong was 'over banked' and that the appropriate response was to restrict new entry to the market.

This diagnosis created a tension between the banks (who lobbied for even more anti-competitive regulation) and the state which, while agreeing that there were too 
many banks, hoped to promote Hong Kong as an international financial centre. This conflict was expressed in the debate over a further moratorium on bank branches in the late 1960s and in the regulation of the non-bank deposit-taking companies that emerged in the international financial boom of the 1970s. Until the moratorium in 1965 there were few non-bank financial companies engaged in international business, but by the early 1970s their numbers had increased to several hundred.

\section{Outline Chronology}

\begin{tabular}{|l|l|}
\hline Interest Rate Agreement & 1964 \\
\hline Moratorium on new bank licences & 1965 \\
\hline Lobbying for Limits on new bank branches & $1966-69$ \\
\hline Barclays Bank seeks licence & $1971-1972$ \\
\hline $\begin{array}{l}\text { Amendment of Moratorium to exclude banks from countries not yet } \\
\text { represented in Hong Kong }\end{array}$ & 1972 \\
\hline Banks lobby for regulation of DTCs & $1973-5$ \\
\hline 3-tier banking system proposed & 1974 \\
\hline Regulation of DTCs introduced & 1975 \\
\hline Moratorium on new bank licences lifted & July 1978 \\
\hline Moratorium on new bank licences re-imposed & August 1978 \\
\hline Moratorium on new bank licences lifted: one office only allowed & 1981 \\
\hline New foreign banks restricted to 3 offices & 1999 \\
\hline Restriction on number of offices lifted & 2001 \\
\hline
\end{tabular}

\section{Operation of the Moratorium as a Barrier for Foreign Banks}

During the early 1970s there were several applications for new licenses made on special grounds, but only one was successful. Barclays Bank first applied for a license in August 1969 but was advised to find a local bank to acquire as a form of entry. In November 1971 they applied for a license in their own name and received the support of the Banking Commissioner. ${ }^{18}$ He made the case to the Banking Advisory Committee (BAC) that no British banks (as opposed to British Overseas banks) had branches in Hong Kong, which was regrettable because of Hong Kong's trade relations with the UK. The added prestige to Hong Kong's IFC of hosting one of the 'Big Four' British banks was also a factor. Finally, Paterson expressed his belief that UK-incorporated banks were never meant to have been considered 'foreign' under the moratorium. A pencilled minute on the HSBC's copy of this document notes 'these are not in my view sound arguments. No’. 
At the same time as the Barclays case was put to the BAC, Paterson also recommended that a Swiss bank be allowed to enter the market. This has never before been noted in the historical account of the moratorium. Given the global importance of the Swiss banking industry, the presence of a Swiss bank would 'contribute significantly to the Colony's prestige'. Moreover, HSBC was trying to open a branch in Switzerland and had been told that reciprocity in Hong Kong would help their application. ${ }^{19}$

The two cases were discussed at the BAC meeting in December 1971. All were agreed that if the Swiss bank put in a formal application then it should be granted on the grounds of promoting the IFC in Hong Kong. In the end, however, a formal application was delayed and the Swiss bank did not enter until after the moratorium was lifted. The case of Barclays was much more controversial. Members were concerned about the threat of competition, and the danger of other large British banks considering this a precedent for their own cases. On the other hand, the members of the BAC were generally agreed about the prestige benefits. Sandberg of HSBC raised the danger that, if refused, Barclays would go to Singapore instead of Hong Kong, an outcome the Financial Secretary, Haddon-Cave, described as 'most embarrassing and politically unfortunate', although the other banks were not so concerned. $^{20}$ After considerable discussion both proposals were approved subject to the proviso suggested by Sandberg that Barclays should make one more attempt to buy a local bank. This delayed the final decision for a further few months.

In early February 1972, a team from Barclays visited Hong Kong and convinced Paterson that they had done all they could to take over a local bank, so they should be granted a license in their own name. The BAC meeting in April 1972 to consider this second request was more reluctant, with most members arguing that Barclays should be required to make yet a further attempt at acquisition. After much grumbling the meeting agreed to recommend that a license be granted but that Barclays be restricted to one office only. Any branch expansion would require Barclays to take over a local bank. $^{21}$ At the last minute, Sandberg of HSBC and Millar of Chartered Bank tried to reverse this decision because there was another foreign bank in take-over negotiations with a local bank, suggesting that this might still be an option 
for Barclays. They were knocked back since the papers were already with the Executive Council who would be meeting in 4 days' time. ${ }^{22}$ In the end, it took three more months for the Executive Council to approve Barclays' application and the office was finally opened on 3 April 1973. Barclays was restricted to operating one branch only and claimed that it intended to focus on the wholesale market, thus fulfilling the government's goal of developing the international financial centre without increasing competition in the local retail market. ${ }^{23}$

The Barclays case did mark a change in the attitude of the government to try to resolve the contradiction between wanting to support the development of the international financial centre in Hong Kong, but not wanting any further competition in the domestic market. They announced a limitation of the moratorium to allow consideration of banks from countries or regions that were not yet represented in Hong Kong. This encouraged more applications but did not result in any new licenses, effectively achieving the goal of showing willingness to support the IFC while not allowing further competition. In July 1973 applications from five banks were put to the BAC, and all but one were rejected. The exception was the Swiss bank discussed earlier and approval was agreed so long as HSBC was allowed to enter Zurich. The banks (and grounds for refusal) were BCCI (too young), Bank Bumiputra Malaysia Berhad (there was already an established Malaysian bank in Hong Kong), and Habib Bank (already turned down in 1969; State Bank of Pakistan would object). The Bank of Tokyo wanted to transfer its license to a new wholly owned locally incorporated bank in order to increase their appeal to other Hong Kong banks and customers. This proposal was rejected because it would set a precedent for other banks to do the same. In October 1973 Continental Bank applied, and in February 1974 First National Bank of Chicago applied. They were rejected on the grounds that there were already several US banks in Hong Kong, and the Continental Bank had a wholly owned subsidiary finance company in Hong Kong (Continental Bank Illinois (HK) Ltd.) 'whose activities are at present unrestricted by law and which can and does, carry on a very extensive banking business outside the scope of the Banking Ordinance'. ${ }^{24}$

In March 1974, Haddon-Cave mentioned in his budget speech that he was reassessing the moratorium, prompting a rush of new interest. In June 1974, six applications were 
put to the BAC of which three were deemed to meet the new criteria, but all were held up until a coherent policy on new licenses could be established, which in the end took a further four years. ${ }^{25}$ One bank was allowed to enter under the name of an existing bank. $^{26}$

When the moratorium was finally lifted in July 1978 there was an immediate rush of applications and within a year 25 new licenses had been approved. On 7 August, after 41 applications had been made, the government announced that it would not be accepting further applications for a period of at least 6 months to allow an evaluation of the impact of new banks on the banking system. In the end six months turned into two years, and the suspension was only lifted in 1981. Even then, however, the rules followed the precedent set by Barclays Bank and new foreign banks were restricted to one office to prevent them competing with existing banks in the domestic market for deposits. This was amended to three offices in 1999 and finally abandoned in 2001.

The archival evidence presented here shows that without the moratorium there would have been more foreign banks in Hong Kong and that most of them would probably have come from the USA since most of the frustrated applications were from US banks. The late 1960s was a time of dramatic expansion in US banks' multinational presence due partly to restrictions at home. For example, from 1965-71 twenty-seven US banks opened offices in London's IFC. The pent up demand for bank licenses shows that there was still belief in the scope for profit in the market from full banking activity that could not be met through finance company subsidiaries. The alternative of opening a finance company had the advantage of not being subject to the banking ordinance, but it could not trade on the international bank's name in the same direct way as a full branch, nor could it get access to cheap retail deposits from the 'general public' or the inter-bank market. Several of the banks that applied for full licenses already had finance companies in Hong Kong, showing that they were not considered substitutes.

\section{The Impact of the Moratorium on M\&A}

One of the government's aims behind the moratorium was consolidation and improvement in management and governance of local banks since foreign banks could only gain access by taking stakes in existing banks, thereby hopefully transferring 
their managerial expertise. ${ }^{27}$ This goal was also consistent with attracting foreign interest in the emerging IFC. In practice, however, it was not easy for foreign banks to acquire stakes in local banks because of their ownership and governance structures. Even after buying an interest in a local bank, the transfer of managerial expertise and re-organisation could be problematic. The goal of consolidation and improvement in management, therefore, was not achieved by the moratorium. There was only one horizontal merger among existing banks when in 1973 the Overseas Trust Bank (with 18 branches) in a period of aggressive expansion took a controlling interest in Hong Kong Industrial and Commercial Bank of Hong Kong (7 offices). OTB, however, later proved that its governance structures were weak when it came under the attention of the Independent Commission against Corruption in 1986 and its officers were convicted of fraud dating back to $1979 .^{28}$

The obstacles to merger included healthy profits and family ownership. In the 1960s most local banks continued under the stewardship of their founder and his family. Figure 1 shows that profitability increased on average for banks in Hong Kong after the moratorium was imposed, which undermined the pressure for mergers. There is no sign here that the entry of 41 foreign banks in 1979 immediately affected the profitability of existing banks. After the moratorium was lifted in 1981, however, when more comprehensive data are available, it is clear in Figure 2 that profitability declined.

[insert Figure 1 and Figure 2 here]

Figure 3 shows that there was no relationship between the size of a bank and its profitability. Eliminating the relatively large Hang Seng Bank from the sample makes the relationship even more remote. Small banks were not, therefore, more susceptible to take-over because of low profits.

[Insert Figure 3 here]

Some indication of the obstacles to foreign acquisition can be seen from the case of Barclays Bank, which made four unsuccessful attempts before asking to open a branch in their own name in 1971. The main obstacles were that the principle 
shareholders of the local bank (often the family of the founder) would not in the end agree to relinquish control, and that banks had inflated views of their market value due to the moratorium. Thus Barclays described how one deal fell through in March 1971 'because the principal shareholder could not bring himself to give us more than a very small interest for several years, and our ideas as to price were a long way apart.' In May 1971 a team flew out from London for negotiations with another bank 'but it became clear that there was dissent among the shareholders as to the policy of bringing in outsiders' although discussions continued to January 1972. A final attempt failed in November 1971 when 'it became clear that the vendors valued their business at very nearly double our starting offer, and we were asked to give a yes-or-no decision within 24 hours.' Paterson, then Banking Commissioner, noted that this last bank had carried on negotiations with no less than nine overseas banks but none of them successfully. ${ }^{29}$ Another of the banks approached by Barclays had been approached by at least five other foreign banks. ${ }^{30}$ This level of activity certainly suggests a healthy appetite for local Chinese banks among the international banking community, but the obstacles were also high. Barclays wearily concluded that 'our inability to get involved with a local bank in Hong Kong has not been for want of trying. ${ }^{31}$

Even if successfully concluded, foreign take-overs were not a reliable solution to poor governance, as is shown in the case of Far East Bank. This case also shows the intransigence of ownership and governance standards that was encouraged by the increased bargaining power of local banks because of the moratorium. Deacon Chiu, a theatre owner in the New Territories, applied successfully for a bank license in 1959 but by 1961 the bank was already under investigation by the Deputy Economic Secretary and then the Financial Secretary. ${ }^{32}$ During the Chinese New Year of 1961 the bank was overdrawn on its clearing account at HSBC by $\$ 200,000$. After meeting with Chiu, Cowperthwaite noted 'I think we will have to continue to watch this bank very carefully. Mr. Chiu gives his manner of thought away when he says 'I' instead of 'the bank'. I read him a lecture about keeping banking business and other business strictly separate, but I am afraid the lesson will require constant repetition., ${ }^{33}$ In the end, the lesson was perhaps not repeated constantly enough.

The Far East Bank was a victim of the 1965 banking crisis (deposits fell from 
HK\$60m in 1964 to HK\$22m by the end of 1965), and was helped by the HSBC until a longer term solution could be found. In 1969, Citibank took a controlling interest (76\%) of the bank leaving $24 \%$ in the control of the founder, Deacon Chiu. Citibank retained control of Chiu's share for several years, however, until he repaid debts to the bank. The avidity of the American bank to take part in the Hong Kong banking market is evident in the terms of the acquisition, which included in Clause 11 that:

Chiu shall continue as a Director and Chairman of the Board during his lifetime and City Bank agree and undertake that he shall not during his lifetime be removed from the position of Director and Chairman of the Board unless he shall be adjudicated, bankrupt, certified insane or shall be convicted of a serious offence which affects adversely his integrity or moral standing in the Colony of Hong Kong. ${ }^{34}$

Citibank soon had cause to regret this concession as Chiu became dis-satisfied with the new management. On 15 February 1979 the board met acrimoniously and Chiu and his two sons left the meeting. Meanwhile, the remaining members of the board voted to hold an EGM to delete the clause that allowed Chiu to remain as Chairman. ${ }^{35}$ Chiu subsequently took members of the Far East Bank board to court to prevent this and won his case since he was not dead or demonstrably insane. In 1982 Citibank extricated themselves from Far East Bank in an agreement by which they took over 11 out of 25 branches of the bank, amounting to $70 \%$ of total loans and $56 \%$ total deposits. In November 1988, Chiu was arrested on charges of false accounting dating back to 1983 and involving \$210m of credit facilities to companies in Hong Kong and the Philippines. The case was then delayed by appeals and judicial review and finally dismissed in 1993 due to Chiu's apparent ill health.

Despite this evidence of obstacles to foreign participation in local banks, the effort to promote consolidation was partially successful and there were a number of important foreign acquisitions in the late 1960s and early 1970s, mainly of medium sized banks. Unlike the pattern of foreign acquisitions in the 1980s these deals were not the result of the failure of the local bank and subsequent match-making by the banking commissioner. Nevertheless, governance problems persisted and two of the banks that attracted a foreign interest in the 1970s were under investigation for corruption by the ICAC by the early 1980s (Ka Wah and Overseas Trust Bank). Hong Kong Industrial and Commercial bank was also caught up in the 1982 crisis. As noted in the case of the Far East Bank, these subsequent events show that foreign acquisition was not 
itself the solution to the problem of poor governance. The hopes of the Financial Secretary that foreign banks would do the job of external supervision did not come to fruition. The major acquisitions of local banks are shown in Table 1, which shows that almost all the acquisitions were in the boom years of the early 1970s, before the global downturn of 1974 .

[insert Table 1 here]

Figure 4 shows the movement in published net profits as a percent of total assets for some of these banks, which shows a rising trend from 1965 until 1973 close to the average performance of our sample of 15 banks. $^{36}$ From 1973, however, by which time most acquisitions had taken place, almost all of the banks under-performed the average until the end of the decade. This is not a full sample and is based on published balance sheets, which reported profits only after transfers to inner reserves. The outcome might also be due to more realistic balance sheet reporting after merger, but it does give a plausible indication that many of the banks with foreign interest underperformed the average after they were taken over but not before. [Insert Figure 4 here]

The failure to learn the lessons of the 1960s is clear in the evidence that new local banks after the moratorium still showed the same weaknesses in the 1980s as in the 1960s despite foreign participation. The first Hong Kong registered bank to gain a license after the lifting of the moratorium was the Sun Hung Kai Bank. The Sun Hung Kai Finance Co Ltd, a registered deposit-taking company, made the application in November 1981, changed its name to Sun Hung Kai Bank Ltd and started offering full banking services at the end of March 1982, shifting its non-banking business to a subsidiary. ${ }^{37}$ The major shareholders of the bank were Paribas (25\%), Merrill Lynch (15\%) and Fung King Hey, founder and chairman (42\%). The bank immediately opened a new head office (the cost of $\$ 300 \mathrm{~m}$ absorbed $70 \%$ of shareholders funds), ${ }^{38}$ added two branches and moved two other branches to ground floor premises to be closer to retail customers. By October 1983 the major shareholders had to make special deposits of HK\$288m as indemnity against bad loans (the total bad loans in the end amounted to $\$ 339 \mathrm{~m}$ ) and the search began for an external saviour. Meanwhile HSBC acted as a lender of last resort and the government allowed the Exchange Fund to place deposits with the bank to enhance liquidity. The agreement for the sale of the bank to Arab Banking Company was concluded March 1985 and 
completed in May 1985, whereby Fung retained only 25\% of the ordinary shares and ABC the remaining 75\%. In July 1985 losses of HK\$229.4m were eliminated by cancelling $\$ 78.1 \mathrm{~m}$ ordinary shares and cancelling the share premium account $\$ 151.3 \mathrm{~m}$. Fung died the following month.

The moratorium was not a direct cause of the governance problems of banks in Hong Kong, but nor was it the solution that the government had hoped it would be. The cost of the failure to resolve the governance problems in the Hong Kong banking system was high for depositors, many of whom lost money from the bank failures of the 1980s, but it was also high for the government and taxpayers. The total cost to the Exchange Fund related to helping seven banks during these years was HK\$3.8b. ${ }^{39}$

\section{Regulating Non-bank Financial Institutions}

Another outcome of the moratorium was an increase in non-bank finance companies, which did not fall into the local definition of 'banking' because they did not use the word 'bank' in their title, and did not serve 'the general public' by offering current account or checking accounts. This meant that they were outside the regulatory and supervisory purview of the Banking Ordinance and outside the Interest Rate Agreement. The perverse impact of anti-competitive regulation, therefore, was an increase in the supply of unregulated and unsupervised financial services that further threatened the stability of the banking system. Many local licensed banks established subsidiaries to operate in this sector. Others were formed by foreign banks that could not gain entry into the retail banking market.

Banks became keenly aware of this competition during the boom of 1973, and in early July the banking members of the BAC called for regulation to restrict the activities of these finance companies. The financial secretary Haddon-Cave was dismissive, arguing that they were not all weak or imprudent, and that the public interest rationale for regulation was not clearly evident. Any legislation would have to be detailed and complex and he concluded that he 'felt such a task to be beyond the present resources available to government. ${ }^{40}$ This set the stage for a running battle between the 'official' (government) and 'unofficial' (banking) members of the BAC.

At the beginning of 1974 Sandberg tried to frighten Haddon-Cave into action by 
threatening that the Interest Rate Agreement was likely to collapse because of the competition from DTCs. This, in turn, would mean higher interest on loans to Hong Kong's industry. Haddon-Cave didn't take up the bait, remarking that the government did not have responsibility for the interest rate structure and that 'there is no doubt that the IRA has worked well and it provides a useful code, though some would query why the price mechanism shouldn't be allowed to determine the price of money as for other commodities'. On the threat of higher interest rates for industrial loans, he suggested that this might be a necessary evil given high interest rates internationally. Overall, his view was that

'the finance companies are now an integral part of Hong Kong's financial sector and they are making a measurable contribution towards our international stature as a financial centre. As far as I can see, it is not within the government's power, nor anyone else's for that matter, to freeze them out. ${ }^{41}$

Under continued pressure to introduce legislation to protect depositors, however, proposals were developed by the new Banking Commissioner, Ockendon. He revealed his recommendations for a 3-tiered banking system of Full Licensed Bank, Limited Licensed Banks and Registered Finance Companies at the June 1974 meeting of the BAC. ${ }^{42}$ In essence, the proposals continued the moratorium on new retail bank licenses but allowed an opportunity for new banks to enter the wholesale market. Only the retail market for small deposits repayable within 3 months would be fully controlled by the existing licensed banks. They would have to compete with new Limited Licensed Banks for large deposits even at short term. The fully licensed banks, with their higher minimum capital and liquidity ratios would also compete directly with Registered Finance Companies for three-month deposits over \$50,000. The proposal to reserve all deposits less than 3 months for the existing banks prompted 'forceful representations' from finance companies, which prolonged the introduction of the new system. ${ }^{43}$ Having established themselves in advance of any guidelines, the finance companies had become entrenched enough to protect their position.

In August 1974 Haddon-Cave circulated the BAC with draft proposals for the Executive Council based on Ockendon's report. These caused considerable indignation and resistance among the banks. Haddon-Cave's draft was particularly critical of the anti-competitive impact of the moratorium, noting that restrictions had 
been imposed at a time of weakness, but

'now, the banking system is strong and healthy and less in need of protection in return for the obligations imposed on it. In principle, protection from competition discourages innovation by those protected and keeps charges unnecessarily high, while its more beneficial effects may become eroded by the diversion of regulated business into unregulated channels. ${ }^{44}$

The banking members of the BAC objected, claiming perversely that Hong Kong's reputation could be impaired by a rapid expansion in the number of banks that the government had responsibility to supervise. They claimed there was strong and healthy competition and 'it is unappropriate [sic] and demeaning to use a loaded expression such as 'protection from competition..... 45

The draft memo went on to conclude that there were probably enough retail banks, but there was room for entry in the wholesale sector. The unofficial members of the BAC responded that the banks had already seen an erosion of their ability to attract funds because of the competition from DTCs not subject to the same restrictions as the banks were (liquidity margins and reporting requirements). The problem, therefore, was not the entry of new banks (who would be subject to the same restrictions as existing banks) but the operation of non-bank institutions outside the regulations that were competing with banks for short term deposits.

The memo set out a choice between control and supervision of DTCs to protect depositors and preserve the stability of the financial system or to impose liquidity requirements and other controls to protect banks from competition. The memo then rejected the second option since 'such control and supervision would require an army of inspectors and could never be fully effective'. Instead, it recommended the three tiered system of full license banks, limited licensed banks, and registered finance companies.

At the September 1974 meeting of the BAC to discuss the draft for the ExCo, no agreement could be achieved. The government's view was that the bankers' proposals for minimum deposits for DTCs 'would be harmful to the present condition of our financial sector as well as being unacceptable to those operating in our markets at present (including those of international repute). ${ }^{46}$ The government was not willing 
to close down these institutions through regulation. However, the Financial Secretary still sought a compromise and was eventually ready to accept the banks' request for registration of DTCs, and minimum paid up capital but with lower minimum deposit requirements. The proposals for limited licensed banks (i.e. new competition for short term deposits) could be shelved for the moment.

Finally, in November 1974, noting that after informal discussion between official and unofficial members of the BAC since September, 'official members now accept that present conditions are unsuitable for a radical reshaping of Hong Kong's financial sector', the Banking Commissioner submitted the compromise proposals for the Executive Council. $^{47}$

1. The proposals for issue of limited banking licences and consequent redefinition of banking business would be left under review.

2. No further bank licenses would be issued until more settled finance conditions prevailed and until better information was available on the scale of operations of finance companies.

3. Some measures to protect smaller depositors will be implemented.

Only banks could accept deposits less than \$50,000, all DTCs would have to register and all must after 2 years have minimum capital of $\$ 5 \mathrm{~m}$ ( $\$ 2.5 \mathrm{~m}$ paid up), provide annual audited accounts available for inspection by the public and displayed at the place of business, and they would pay an annual fee to cover administration of the new rules. The Banking Commissioner reserved the right to call for further information to check compliance. DTCs were also prevented from lending more than $25 \%$ of paid up capital and reserves to any one person or company, and they had the same requirements as banks over lending to directors and relatives. The proposals were duly put to the Executive Council and then to the Legislative Council in January 1975.

The banks lost their battles over the minimum size of deposit, and minimum duration, which were much lower than they had wished. What had seemed at the outset to be a simple matter of protection of depositors in July 1973 grew into a prolonged and bitter battle between Haddon-Cave and the banks over the protection of the banking market in Hong Kong. It took 18 months for agreement in principal to be achieved and a further year for the bill to become law in January 1976 when 176 DTCs were registered. Prudential supervision of DTCs was enhanced at the end 1978 by requiring monthly returns, just after a run on Sun Hung Kai Finance Co. in 
November of that year required lines of credit from HSBC and Paribas. ${ }^{48}$ The implementation of physical inspections, however, was delayed by recruitment and training of staff and did not begin until January 1980. By June 1980 the Banking Commissioner Colin Martin warned that he had no discretion over who successfully registered a DTC so long as they complied with the basic legal requirements, and so it was up to customers to assure themselves of the quality of the DTCs they did business with. $^{49}$. The Three-Tiered System was finally introduced in 1981, seven years after it was first proposed and a prolonged banking crisis began in 1982.

\section{Restrictions on Expanding Branch Networks}

The anti-competitive regulations introduced in the mid-1960s went further than most international financial centres, but they did not satisfy the desire of local banks for protection from non-bank financial institutions as was revealed in the previous section. The desire to gain protection from foreign banks already operating in the colony before the imposition of the moratorium was a third avenue for local banks to lobby the government for protection. After price competition was curtailed by the controls on deposit interest, banks had to rely on non-price competition to get access to funds, such as the provision of other services (safety deposit, foreign exchange), location, convenience, personal service, and reputation. The high profile of local branching activity in the discussions among banks suggests that this was an important form of competition both to attract local deposits and to gain local lending opportunities. A bank that could not develop a branch network had to rely on the more expensive inter-bank market to get funds, or take on exchange risk by transferring funds into the colony. Figure 5 shows the most rapid growth in branch activity in Hong Kong in the first half of the 1960s and again in the early 1970s.

[insert Figure 5]

The rapid expansion of branch networks was a common feature at this time. The OECD reported that 'practically all countries have seen a spectacular extension of the banking network in the sixties and seventies either though branching by existing banks or, in some countries, also by the setting up of new banks.' Moreover, 'a striking feature of this early phase of private customer acquisition was that price competition was hardly used as this was considered by the banks as too costly and inefficient and was moreover in conflict with current banking practice and official restrictions on deposit rates applying at that time in most countries'. ${ }^{50}$ The most 
notable example was the proliferation of branches in the USA while Regulation Q (a ceiling on deposit interest payable) was in force. Hong Kong's development thus reflected global trends in banking as well as local factors.

Locally, demographic change was an added factor encouraging the increase in branch networks. As the large refugee population was resettled into new state housing in purpose-built sites, this increased the opportunities for new branches. In 1963, for example, the Chartered Bank applied to the Government to open a 'Squatter Bank' in the temporary squatter area of Wan Tai Sin 'realising that many of the squatters were far from penniless'. ${ }^{51}$

The increase in the number of branches prompted calls to restrict this form of competition, particularly by foreign banks. The case for new rules was based on a variety of premises. First, the government worried that opening branches was costly and could undermine the solvency of small banks that expanded too quickly. Secondly, local banks were hostile to competition from foreign banks operating in Hong Kong, some of whom were becoming increasingly competitive in the local retail market. Thirdly, large local banks frequently faced barriers to entry in overseas markets and sought reciprocity as a lever to overcome these obstacles.

By 1965 there were 29 foreign banks operating in Hong Kong (excluding HSBC, which was registered locally). These included a group of overseas Chinese banks from Singapore, Malaysia and Indonesia that specialised in regional trade finance. They tended not to open branches to participate in the local credit market. The European and American banks, however, did branch extensively after 1959. Chartered Bank had the largest network (17 branches by 1965) followed by Banque Belge pour l'Etranger with five branches in 1965. HSBC complained particularly about American bankers as 'fierce competitors who keep to no rules, and surely it is good policy to make things as expensive and as difficult for them as possible. ${ }^{52}$ In 1964 Jake Saunders, chief manager of HSBC, observed of American banks that 'I am afraid there is no doubt that they want to dominate the financial scene in South-East Asia'. ${ }^{53}$

As shown in Figure 5 there was a surge of branching activity in the years running up to the introduction of the moratorium in 1965, but most of this was local bank 
expansion. In total, the number of bank branches increased from 38 to 101 in 1961 alone, but only 5 of these were branches of foreign banks. By 1970, however, foreign banks had increased their share of total branches from 8\% to 13\%. Table 2 shows the networks for different categories of bank in Hong Kong during the second surge in the number of branches between 1970 and 1973. This shows the rapid expansion of foreign banks compared to local or note-issuing banks (although they increased their share of total branches only from $13 \%$ to $16 \%)$. The most prominent foreign banks were Citibank with 6 branches in 1970, followed by Banque Belge pour l'Etranger, Banque Nationale de Paris and International Bank of Commerce (a US-owned bank) with four branches each. Citibank became a very aggressive player in the domestic system, opening 43 branches by 1981. In 1970 the two banks with by far the most extensive networks were the note-issuing banks HSBC (62) and Chartered Bank (25), both of whom lobbied vigorously for restrictions on other banks extending their networks.

[insert Table 2 here]

In 1966 (exactly one year after the moratorium on new bank licences had been imposed), the HSBC complained to the Financial Secretary that applications to open branches in San Francisco and Singapore and been refused on the grounds that local authorities there believed the area was already adequately supplied with banking services. $^{54}$ HSBC hoped that the government would retaliate by restricting the branching of banks from these countries. Carruthers of HSBC wrote to Cowperthwaite, the Financial Secretary: 'we feel very strongly that you should seek authority to prohibit those foreign banks whose country or state imposes restrictions on branches of foreign banks from opening further branches in the colony, 55 The HSBC's motive, therefore, was clearly defensive and related to their international expansion.

Cowperthwaite replied that he had been considering developing powers for the Banking Commissioner to control branching, but his motives did not match those of the HSBC. As he explained to Carruthers: 'The clause is primarily intended to give the government power to control to some extent the extension of the activities of banks which are known to be over-stretched or otherwise operating in ways contrary to the interest of the community though as a matter of general policy it could be used to prevent branch openings for other valid reasons.' He explicitly rejected the 
possibility of using such powers to restrict branches in areas that were over-banked, 'as this is contrary to our normal philosophy here of freedom to compete'. ${ }^{56}$ The concern that banks might over-extend themselves arose from the case of the Far East Bank, which had an unusually large branch network for a local bank (13 branches) but suffered during the 1965 banking crisis from a loss of deposits and had to be nursed by the HSBC.

At the September 1966 Banking Advisory Committee meeting, the Financial Secretary conceded that the issue of reciprocity would be considered when new branches were authorised. In turn, the members of the BAC agreed on three conditions for branch expansion by local banks: an assessment of whether the new branch would over-extending its resources was a 'prime consideration'. Secondarily, the competitive position in the proposed locale 'might be' taken into account. ${ }^{57}$

The Banking Ordinance was duly amended in 1967 to require banks to obtain approval from the Banking Commissioner to open new branches and introducing a \$1000 fee (hardly prohibitive even for the smallest bank). Debate continued, however, over the criteria under which the authority to open a new branch should be given. The Far Eastern Economic Review reported that some foreign banks were refused permission to open branches in 1968, although this decision had been reversed in the case of National City Bank due to the long time the bank had been represented in Hong Kong. ${ }^{58}$ In 1968 the only foreign banks to open branches (and the number) were the Chartered Bank (3), National City Bank (2) and Banque de l'Indochine (1). In addition, local banks opened 11 branches altogether (of which 5 were HSBC).

The banks' motivation for restricting branch expansion was clearly aimed at restricting competition from foreign banks rather than concern for the banking system as a whole, and they found an ally in the Banking Commissioner, Leo Cole. Cole was vitriolic in his condemnation of foreign banks in the Colony. He described them to HSBC chief manager J.H. Saunders in May 1968 as 'parasitic invasions' that contribute little or nothing in the way of support and assistance to the colony and they bring very little in. They perform no function within the colony which cannot be adequately fulfilled by the colony's own banks, apart from representation. ${ }^{59}$

The charge of parasitic behaviour is difficult to substantiate. Excluding the 
note-issuing banks (which were not included in Cole's definition of 'foreign') the ratio of local advances to local deposits for foreign banks was $115 \%$ in 1968 , implying a net inflow of funds from abroad rather than a drain. This ratio was also twice as high as the local banks (56\%). On the other hand, Mainland banks controlled by the Bank of China took in deposits but did not lending locally. Their ratio of advances to deposits was a mere $39 \%$ because they channelled their liquidity across the border to the Mainland. While the Mainland Chinese banks were mostly foreign registered, they were never specifically mentioned in the debate over competition. The focus was squarely on American and European banks. More telling is the second sentence of this quotation, which refers to the competition posed by foreign banks.

Table 3 shows the distribution of deposits and advances for different categories of bank. Competition for deposits for local banks in the mid-1960s was coming from the note-issuing banks (in particular the HSBC and Chartered Bank) and not from the foreign banks. But the note-issuing banks were the instigators of anti-competitive regulation, not the target of the lobbying. On the other hand, foreign banks were collectively increasing their share of advances.

[insert Table 3 here]

In April 1968, three years into the operation of the moratorium on new licenses, 24 local banks wrote to the Banking Commissioner, Leo Cole, to urge further controls on branch expansion, appealing to the dangers to stability: 'Hong Kong already has too many banks, and as a result of severe competition, customers have been, and are, offered large amounts of banking facilities, thus encouraging unhealthy overtrading, ${ }^{60}$ At the same time, Lee Wing Heng, Sub-Manager of Hang Seng Bank complained that deposits had been rising but that there were few outlets for lending. ${ }^{61}$ At a Banking Advisory Committee meeting in June 1968, QW Lee as manager of Hang Seng went so far as to call for all local Hong Kong business to be restricted to local Hong Kong banks. Chau Kai-Yin, on behalf of all the authorised local banks, agreed that foreign banks were 'interfering with domestic banking' and threatening local banks' business. ${ }^{62}$ Cowperthwaite continued to resist extra restrictions foreign banks, arguing that smaller local banks were feeling the pinch from large local banks as well as large foreign banks. Cole responded that the large local banks could offer support to smaller banks in time of need, whereas the foreign banks did not and so 
they should be treated less generously.

After much debate, the BAC put three views to the Governor in Council to restrict further the local activity of foreign banks. ${ }^{63}$

1. The majority of bank members and Leo Cole recommended that foreign banks already in Hong Kong should be entitled to one office in Hong Kong and one in Kowloon. They should be allowed to branch elsewhere only provided they could demonstrate a need, local banks would not be affected and that the principle of reciprocity held.

2. The Financial Secretary, Mardulyn (Banque Belge pour l'Etranger) and the Registrar General preferred no restrictions on branches once a foreign bank had been allowed into Hong Kong. As a compromise (if this was not acceptable) foreign banks should be allowed to branch freely in the main business areas but not where banking was largely domestic.

3. Francis Zimmern, a prominent businessman, argued that all banks applying to open a branch should have to justify need and ability to sustain it, making the policy non-discriminatory.

At this point there were applications from three foreign banks to open simultaneously a total of 12 new branches outside the Central business district of Hong Kong. ${ }^{64}$ At the beginning of 1969 all applications for new bank branches were held in suspense while a general policy was devised. ${ }^{65}$ The Governor, perhaps surprisingly given the weight of opinion in the BAC, opted to accept Zimmern's suggestion and avoid discriminating between foreign and local banks. The criteria for new branches of all banks were to be the resources of the bank and the need to avoid an excess of banking facilities in any particular area. ${ }^{66}$ There was no guidance, however, on how 'an excess of banking facilities' was to be determined. The principal of reciprocity had already been agreed as a further informal criterion. This rubric was evidently not effectively binding since the number of bank offices increased from 274 at the end of 1968 to 326 by the end of 1970 (an increase of 19\%). In 1969 alone five foreign banks opened new branches.

This section has shown how the moratorium on new bank licenses and the interest rate agreement together were deemed insufficient protection from competitive pressures because they encouraged non-price competition in the form of branch networks. The banks found support from the Banking Commissioner but not from the Financial Secretary or the Governor who remained focused on systemic stability as a rationale for regulation, which ruled out discrimination against foreign banks. The data show 
that competition from the note-issuing banks was much more keen than the competition from other foreign banks, and that foreign banks were not a net drain on the colony as was claimed. However, the note-issuing banks used the support of the local banks to press for further protection from foreign competition. In the end, without the support of the Financial Secretary, the banks were not able to restrict existing foreign banks’ access to the domestic market through branch expansion.

\section{Conclusions}

During the 1960s and 1970s many governments restricted foreign bank entry and imposed capital controls in order to protect incumbents and insulate their banking systems from international instability. This offered opportunities for more open IFCs like London and Hong Kong to take advantage of the rapid escalation in international financial and banking activity. Nevertheless, even in a 'laissez-faire' regime such as Hong Kong the tension between hosting an international financial centre and protecting incumbents led to ongoing conflict between banks and the government. The presence of foreign banks in Hong Kong was a hotly contested issue in the 1960s and 1970s as Hong Kong's IFC developed. In the case of restrictions on branches, the local banks lost the battle for further protection from foreign banks' activities but they did gain considerable protection through the strict operation of the moratorium on new licences, which they were able to influence administratively through the Banking Advisory Committee. Even once the rules were changed to allow some foreign banks to enter to build up the IFC, they granted only one new license. On the other hand, the government's reluctance to regulate deposit-taking companies reflected the Financial Secretary's efforts to promote wholesale banking while protecting local banks’ retail operations.

The fact that there was no banking crisis until after the moratorium was finally lifted in 1981 might suggest that the moratorium did work to improve the stability of the banking system. The account based on archival evidence presented in this paper, however, suggests that the moratorium failed in many of its goals, particularly the improvement of governance. The main results were increased non-price competition, increased profits, and a rise of institutions outside prudential supervision. The problems of poor governance that had plagued the banking system in the early 1960s continued. Many of the banks involved in the scandals that led to the crisis of 1982-86 
had foreign partners but this did not resolve their governance problems and they continued to be controlled by families with inter-linking business groups. ${ }^{67}$ This left the banking system vulnerable to contagion from unsupervised non-banks as well as to asset market shocks, particularly property values that were a precipitating factor in the 1982-86 crises.

While the banks (both large and small) lobbied for the moratorium for anti-competitive reasons, the government supported it in order to encourage foreign banks to do the job that prudential supervision and regulation was meant to do, i.e. improve management and governance. However, the protection afforded to small banks by the moratorium and the interest rate cartel worked against this outcome. Higher profits and greater franchise value improved the bargaining power of local banks and reduced the incentive for horizontal mergers. At the same time the moratorium reduced the regulatory space by prompting the rise of non-bank financial institutions that ultimately threatened systemic stability through their links to banks and through contagion. The fact that owners of banks did not themselves view DTCs as a substitute for fully licensed banks, and that once the moratorium was lifted the market share of DTCs dropped away suggests that if the moratorium had not been in place there would have been more banks within the supervisory realm of the government. The moratorium therefore did not achieve its goal of solving the underlying weaknesses of governance in the Hong Kong banking system that resurfaced in the crises of 1982-1986. 
Figure 1

Return on Assets for a Sample of 15 Hong Kong Banks 1964-1980

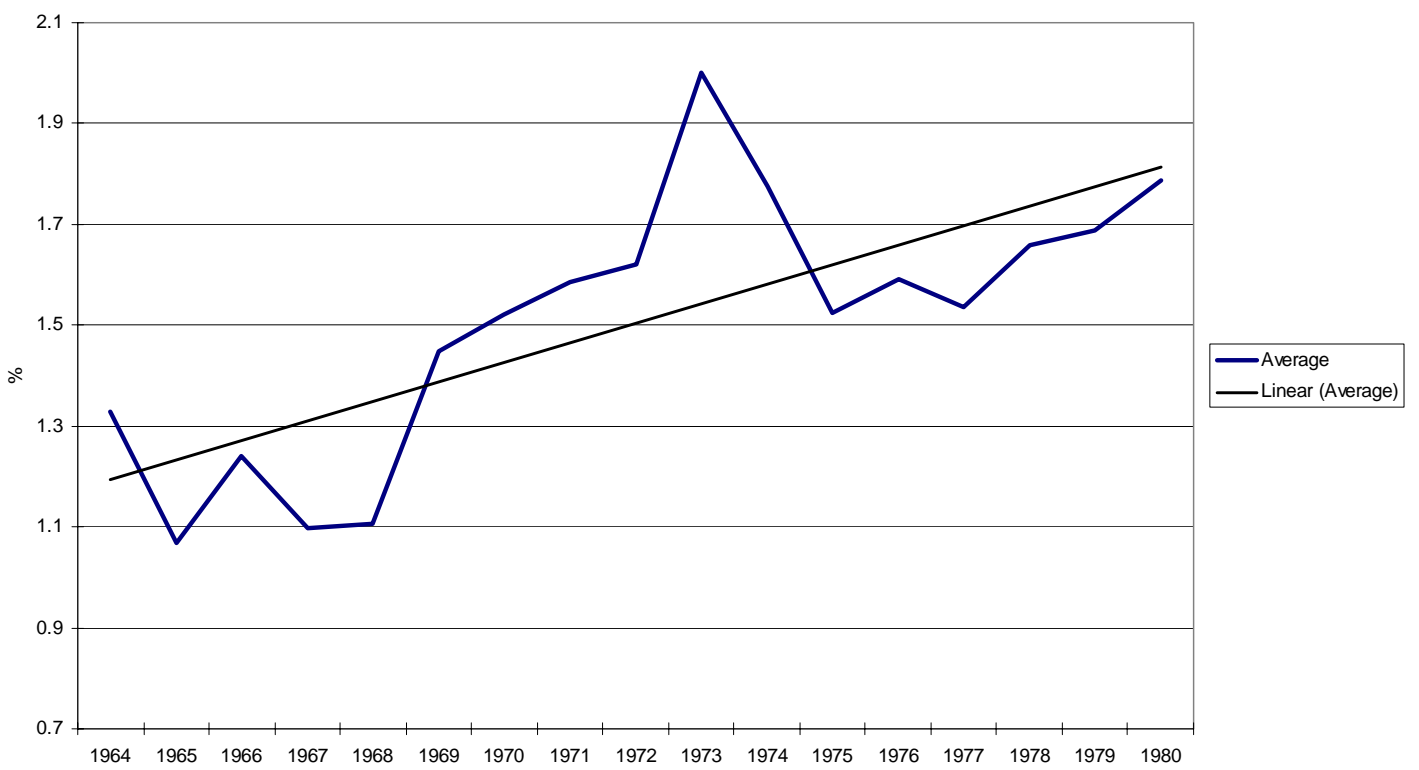

Source: Published balance sheets for 13 banks. ${ }^{1}$ Chartered Bank archives, Guildhall Library. King (1991) for HSBC.

Figure 2

Return on Assets of Licensed Banks in Hong Kong (income-costs/assets)

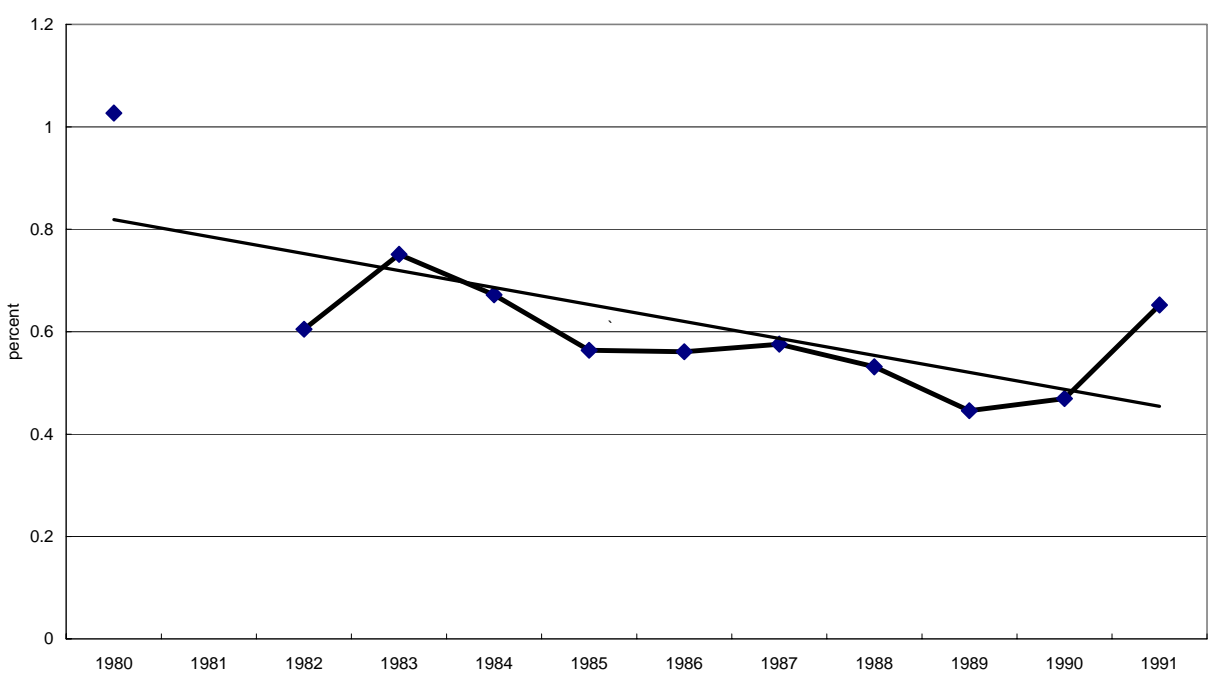

Source: Census of Storage, Communications, Financing, Insurance and Business Services, Census and Statistics Department, Hong Kong. 
Figure 3

Size of total assets and net earnings/net worth: 1977

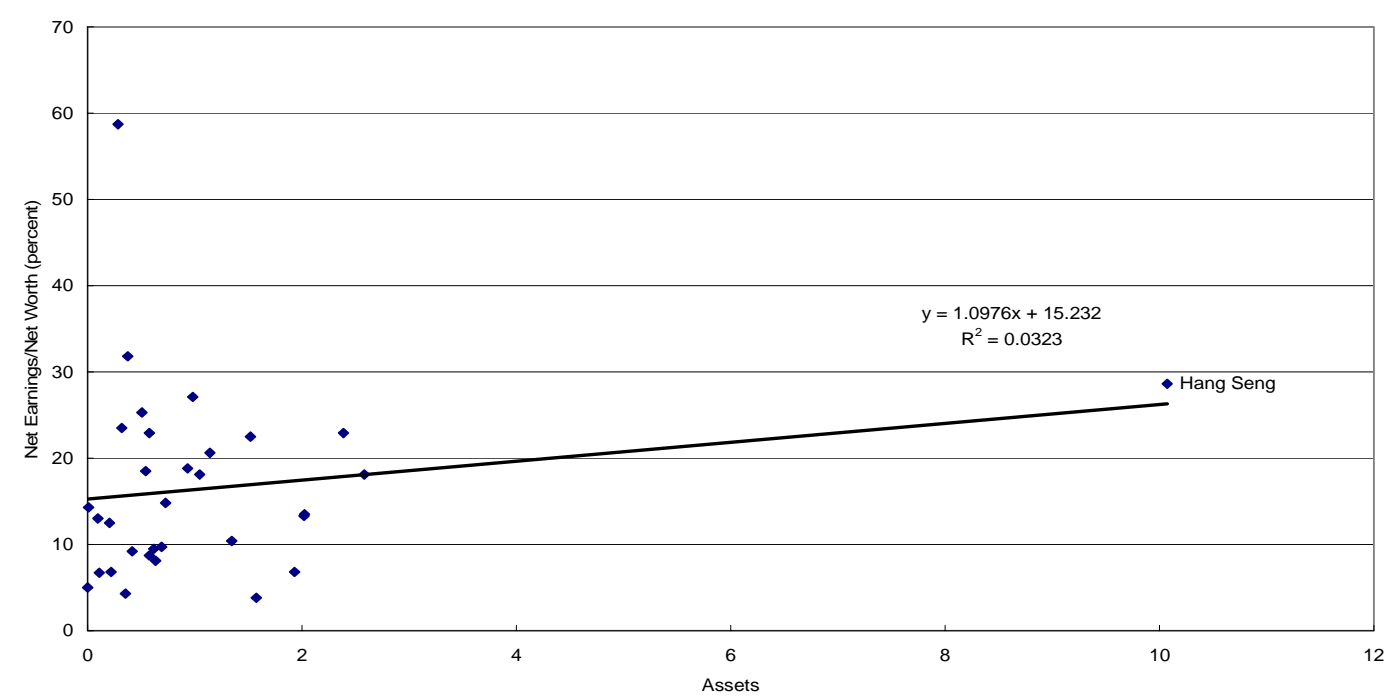

Source: SGV-Sun Hung Kai Ltd., A Study of Domestic Commercial Banks in Hong Kong, December 31, 1978.

Figure 4

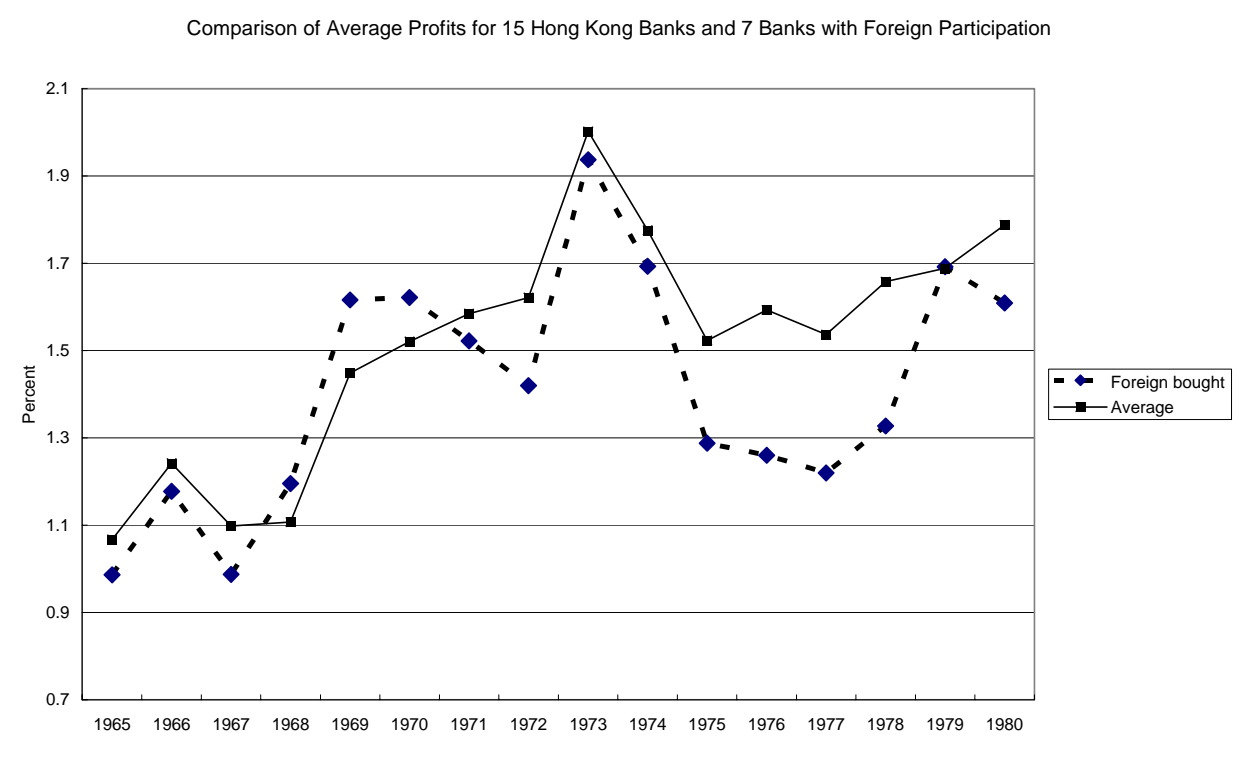


Figure 5

Expansion of Bank Offices in Hong Kong 1954-1980

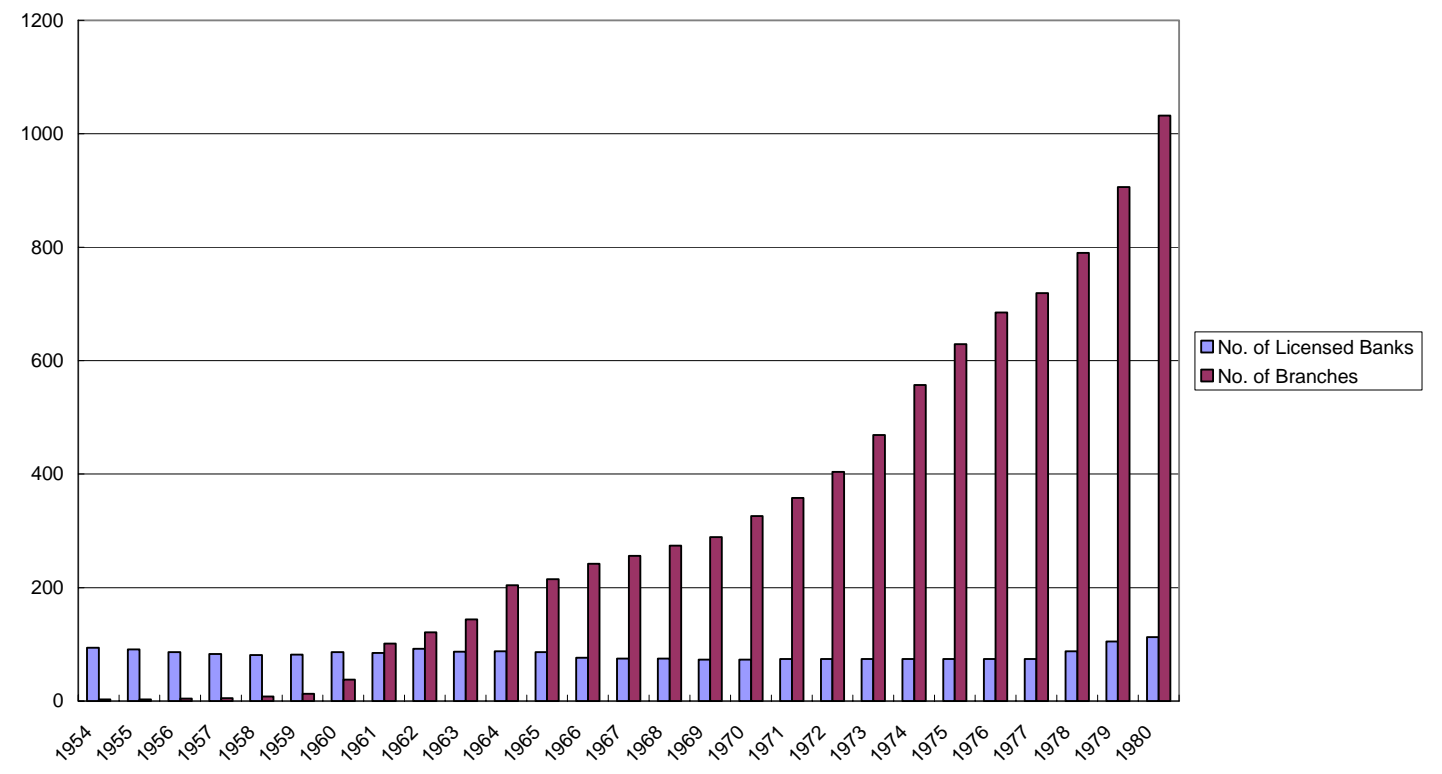

Source: HKIMR Historical Database https://www.hkimr.org/history_database.asp 
Table 1 Foreign Interest in Hong Kong Banks 1969-79

\begin{tabular}{|l|l|l|}
\hline Parent & Majority Interest & Minority Interest \\
\hline First National City & Far East Bank (1969) & \\
\hline National and Grindlays & Dao Heng (1970) & \\
\hline Hawaii Thrift and Loan Co. & Ka Wah (1970) & \\
\hline CS Low Investment Ltd & Ka Wah (1974) & \\
\hline Security Pacific National Bank & Bank of Canton (1971) & \\
\hline $\begin{array}{l}\text { International Consolidated } \\
\text { Investments Ltd (Toronto } \\
\text { Dominion Bank) }\end{array}$ & Overseas Trust Bank (1970) & \\
\hline $\begin{array}{l}\text { International Consolidated } \\
\text { Investments Ltd/ Toronto } \\
\text { Dominion Bank }\end{array}$ & $\begin{array}{l}\text { Hong Kong Industrial and } \\
\text { Commercial Bank (1970) }\end{array}$ & \\
\hline Irving Trust & Wing Hang (1973) & \\
\hline Fuji Bank & Kwong On Bank (1973) & \\
\hline BCCl & Hong Kong Metropolitan (1979) & \\
\hline Swiss Bank Corp & Hong Kong Metropolitan (1974) & $\begin{array}{l}\text { Commercial Bank of } \\
\text { Hong Kong (1972) }\end{array}$ \\
\hline Tokai Bank & & $\begin{array}{l}\text { Commercial Bank of } \\
\text { Hong Kong (1966) }\end{array}$ \\
\hline Bangkok Bank & Wing Lung Bank (1973) \\
\hline Chartered Bank & $\begin{array}{l}\text { Shanghai Commercial } \\
\text { Bank (1969) }\end{array}$ \\
\hline Wells Fargo & $\begin{array}{l}\text { Liu Chong Hing Bank } \\
(1973)\end{array}$ \\
\hline Mitsubishi Bank & $\begin{array}{l}\text { Chekiang First Bank } \\
\text { (1962) }\end{array}$ \\
\hline Daiiichi Kangyo Bank & & \\
\hline
\end{tabular}

Table 2 Branch Networks - totals exclude head office

\begin{tabular}{|l|r|r|r|}
\hline & 1970 & 1973 & Percent Change \\
\hline Foreign & 39 & 64 & 64 \\
\hline Local & 116 & 168 & 36 \\
\hline Note Issuing & 89 & 111 & 25 \\
\hline Mainland Chinese & 45 & 61 & 36 \\
\hline TOTAL & 289 & 404 & 40 \\
\hline
\end{tabular}

Note: note-issuing banks are HSBC, Chartered Bank and Mercantile Bank 
Table 3 Share of Total Deposits and Advances of the Banking System (Percent)

\begin{tabular}{|c|c|c|c|c|c|c|}
\hline & $\begin{array}{l}\text { Share of } \\
\text { Deposits } \\
1964\end{array}$ & $\begin{array}{l}\text { Share of } \\
\text { Deposits } \\
1968\end{array}$ & $\begin{array}{l}\text { Share of } \\
\text { Deposits } \\
1972\end{array}$ & $\begin{array}{l}\text { Share of } \\
\text { Advances } \\
1964\end{array}$ & $\begin{array}{l}\text { Share of } \\
\text { Advances } \\
1968\end{array}$ & $\begin{array}{l}\text { Share of } \\
\text { Advances } \\
1972\end{array}$ \\
\hline $\begin{array}{l}\text { Foreign } \\
\text { Banks }\end{array}$ & 16 & 12 & 13 & 22 & 25 & 30 \\
\hline $\begin{array}{l}\text { Local } \\
\text { Banks }\end{array}$ & 34 & 31 & 35 & 35 & 30 & 32 \\
\hline $\begin{array}{l}\text { Note } \\
\text { Issuing } \\
\text { Banks }\end{array}$ & 40 & 45 & 44 & 36 & 38 & 33 \\
\hline $\begin{array}{l}\text { Mainland } \\
\text { Chinese } \\
\text { Banks }\end{array}$ & 10 & 11 & 8 & 7 & 7 & 5 \\
\hline
\end{tabular}

Source: HKRS 163-1-3273, 163-1-3277, 163/9/371 


\section{BIBLIOGRAPHY}

Allen, F and D Gale, Comparing Financial Systems, MIT Press, 2000.

Beck, T., A. Demirguc-Kunt and R. Levine, 'Bank Concentration and Crises’, World Bank Policy Research Working Paper 3041 (2003).

Berger, A.N., I Hasan and LF Klapper, 'Further evidence on the link between finance and growth: an international analysis of community banking and economic performance', Journal of Financial Services Research. 25. 2004, pp. 169-202.

Claessens, S., A. Demirgüç-Kunt and H. Huizinga, 'How does foreign entry affect domestic banking markets?', Journal of Banking and Finance, 25(5), 2001, pp. 891-911.

Ghose, T.K., The Banking System of Hong Kong, 2ed., Butterworths, 1995. Goodstadt, L. Profits, Politics and Panics; Hong Kong's banks and the making of a miracle economy, 1935-1985. Hong Kong: Hong Kong University Press. 2007. Greenwood, J., Hong Kong’s Link to the US Dollar; origins and evolution, (Hong Kong: Hong Kong University Press), 2008.

Jao, Y.C., Hong Kong as an International Financial Centre; evolution, prospects and policies. Hong Kong: City University of Hong Kong Press. 1997.

Jao, Y.C., Banking and Currency in Hong Kong. London: Macmillan. 1974.

Jao, Y.C., 'Recent Banking Crises in Hong Kong and Taiwan’, in MK Nyaw and CY Chang eds., Chinese Banking in Asia's Market Economies, Chinese University of Hong Kong, 1989.

Schenk, C.R. Hong Kong as an International Financial Centre; emergence and development. London: Routledge. 2001.

Schenk, C.R., 'Finance of Industry in Hong Kong 1950-70; a case of market failure?', Business History, 46(4), pp. 583-608, 2004. 
C.R. Schenk, 'Banking Crises and the Evolution of the Regulatory Framework in Hong Kong 1945-70’, Australian Economic History Review, 43(2), pp. 140-154, 2003.

C.R. Schenk, 'International Financial Centres; 1958-1971: competitiveness and complementarity’, S. Battilossi and Y. Cassis eds., European Banks and the American Challenge; competition and cooperation in international banking under Bretton Woods, Oxford University Press, 2002, pp. 74-102.

Smith, H John Stuart Mill's other island; a study of the economic development of Hong Kong. London: Institute of Economic Affairs. 1966. 


\section{REFERENCES}

${ }^{1}$ From 1965-71, 69 foreign banks opened branches in London, of which almost 40\% were American banks. Schenk, 'International Financial Centres’.

${ }^{2}$ For a survey see, S. Claessens et. al.'How does foreign entry affect domestic banking markets?’.

${ }^{3}$ YC Jao, Hong Kong as an International Financial Centre.

${ }^{4}$ H. Smith, John Stuart Mill's other island.

${ }^{5}$ Friedman, ‘Hong Kong Wrong’.

${ }^{6}$ M. Friedman, 'The Hong Kong Experiment'.

${ }^{7}$ Schenk, Hong Kong as an International Financial Centre.

${ }^{8}$ Goodstadt, Profits, Politics and Panics. Ch. 8.

${ }^{9}$ Beck et. al., 'Bank Concentration and Crises'. The G10 Working Party on

Consolidation in the Banking Industry (January 2001) concluded that consolidation in the 1990s was likely to undermine systemic stability.

${ }^{10}$ Allen and Gale, Comparing Financial Systems.

${ }^{11}$ Berger et al, 'Further evidence'.

${ }^{12}$ Beck et al, 'Bank concentration’.

${ }^{13}$ Schenk, 'Finance of Industry'.

${ }^{14}$ Claessens et. al., 'How does foreign entry'.

${ }^{15}$ Goodstadt, Profits, Politics and Panics. Greenwood, Hong Kong’s Link..

${ }^{16}$ Schenk, Hong Kong as an International Financial Centre, p. 63-66.

${ }^{17}$ Jao, Banking and Currency in Hong Kong. Schenk, 'Banking Crises'. Goodstadt, Profits, politics and panics.

${ }^{18}$ Memo for BAC on Review of Policy on Banking Licences, 25 November 1971. HSBC Group Archive [hereafter HSBC], Chairman’s Papers, BAC 1971. The Big 
Four British banks were Natwest, Barclays, Lloyds and Midland, none of whom had branches in Hong Kong..

${ }^{19}$ Memo for BAC on Review of Policy on Banking Licences, 25 November 1971. HSBC, Chairman’s Papers, BAC 1971.

${ }^{20}$ Minutes of BAC, 3 December 1971. HSBC, Chairman’s Papers, BAC 1971.

${ }^{21}$ Minutes of BAC, 7 April 1972. HSBC, Chairman’s Papers, BAC 1972.

${ }^{22}$ Minutes of BAC 7 July 1972. HSBC, Chairman’s Papers, BAC 1972.

${ }^{23}$ Far Eastern Economic Review, 9 April 1973.

${ }^{24}$ Memo by Banking Commissioner for the BAC, 8 October 1973. HSBC, Chairman's Papers, BAC 1973. Memo by the Banking Commissioner for BAC, 7 February 1974. HSBC, Chairman’s Papers, BAC Minutes 1974.

${ }^{25}$ The banks were Natwest, Lloyds Bank International, Uban-Arab Japanese Finance, Bankers Trust, Chemical Bank and CIBC. The first three were deemed eligible under the new geographical criteria, the two American banks were not and the Canadian bank was rejected because of the lack of reciprocity. Memo for the BAC, June 1974. HSBC, Chairman’s Papers, BAC 1974. The issue of new licenses was suspended during the debate about introducing a Three Tiered System in 1974, which is discussed below.

${ }^{26}$ Underwriters Bank Inc. applied to surrender their license in February 1972 in favour of a new bank to be called Underwriters Bank (Overseas) Ltd. registered in the Cayman Islands with Manufacturers Hanover Trust as the major partner. Memo for BAC 18 February 1974. The BAC agreed in June 1974. HSBC, Chairman’s Papers, BAC, Minutes 1974.

${ }^{27}$ Cole made this explicit in 1968. Leo Cole to Jake Saunders, 2 May 1968. HSBC, Chairman’s Papers, BAC 1968. 
${ }^{28}$ The Chairman and other bank officers were implicated in a cheque-kiting scheme that began in 1979 .

${ }^{29}$ Minutes of BAC, 7 April 1972. HSBC, Chairman’s Papers, BAC 1972.

${ }^{30}$ Comment by Paterson, Minutes of BAC, 7 July 1972. HSBC, Chairman’s Papers, BAC 1972.

${ }^{31}$ Anonymised letter from Barclays Bank circulated to the BAC, 22 February 1972. HSBC, Chairman’s Papers, BAC, 1972.

${ }^{32}$ At the end of 1960 the accounts showed HK\$3.9m in deposits, \$2.9m in loans and \$3.9m in investments, of which 70\% was in land in Tsuen Wan, most of which was held in Chiu's own name rather than that of the bank. HKRS934-7-104.

${ }^{33}$ Note by JJ Cowperthwaite of a meeting with D. Chiu, 10 March 1961. HKRS934-7-104.

${ }^{34}$ Quoted in Judgement of Justice. McMullen, in the High Court of Hong Kong, 21 May 1979. HCA000931/1979.

${ }^{35}$ Ibid.

${ }^{36}$ The banks included with foreign interests are Wing Lung, Overseas Trust, Shanghai Commercial, Ka Wah, Kwong On, Dao Heng, Commercial Bank of Hong Kong.

${ }^{37}$ The information on the Sung Hung Kai Bank is drawn from its published annual reports.

${ }^{38}$ Ghose, Banking System of Hong Kong, p. 90.

${ }^{39}$ Ibid, p. 96.

${ }^{40}$ Minutes of BAC, 5 July 1973. HSBC, Chairman’s Papers, BAC, 1973.

${ }^{41}$ Haddon-Cave personal letter to Sandberg, 19 January 1974. HSBC, Chairman’s Papers, Papers for BAC 1974.

${ }^{42}$ Minutes of the BAC, 28 June 1974. HSBC Minutes of BAC 1974. 
${ }^{43}$ Draft Memo for Executive Council, 8 August 1974. HSBC BAC Papers 1974.

${ }^{44}$ Ibid.

${ }^{45}$ Draft response to the Exco draft by unofficial members of the BAC, 24 August

1974. HSBC, BAC Papers 1974.

${ }^{46}$ Haddon-Cave to Sandberg, 13 September 1974. HSBC, BAC Papers 1974.

${ }^{47}$ Memo for BAC, November 1974, HSBC, Chairman’s Papers, BAC $1974 .$.

${ }^{48}$ Confidence in SHK Finance was rocked by losses reported by its sister company

SHK Securities. Paribas had a 17\% interest in SHK Securities.

${ }^{49}$ Speech by Commissioner of Banking, 10 June 1980. This was reported also in the press.

${ }^{50}$ Competition in Banking, OECD, 1989, pp. 24-25.

${ }^{51}$ Government Information Service, 1963. Hong Kong Public Records Office [hereafter HKRS]365-1-105.

${ }^{52}$ SWP Perry-Aldworth (Senior London Manager HSBC) to GOW Stewart (Manager, HSBC Hong Kong), 15 June 1959. HSBC Chairman’s Papers Carton 4, BBME 1959.

53 JAH Saunders to A Morse, 18 September 1962. HSBC Chairman’s Papers Carton 5, correspondence of A Morse.

${ }^{54}$ MG Carruthers to DA Clinton (deputy Financial Secretary), 31 May 1966. HSBC, Chairman’s Papers, Banking Advisory Committee (BAC).

${ }^{55}$ MG Carruthers to Cowperthwaite, 12 April 1966. HSBC, Chairman’s Papers, BAC.

${ }^{56}$ Cowperthwaite to Carruthers, 8 June 1966. HSBC, Chairman’s Papers, BAC.

${ }^{57}$ Minutes of the BAC, 9 September 1966. HSBC, Chairman’s Papers, BAC 1966.

${ }^{58}$ Far Eastern Economic Review, April 17 1969. p. 184.

${ }^{59}$ Leo Cole to Jake Saunders, 2 May 1968. HSBC, Chairman’s Papers, BAC 1968.

${ }^{60}$ Letter to Cole signed by 14 unauthorised banks, 19 April 1968. HSBC GHO322/4 
Hang Seng Bank Ltd 1968.

${ }^{61}$ Similar complaints were made again by Hang Seng Bank in August 1971. Report for the Chairman of HSBC by PE Hutson, 16 September 1971, HSBC GHO322/7.

${ }^{62}$ Minutes of the BAC, 28 June 1968. HSBC, Chairman’s Papers, BAC 1968.

${ }^{63}$ Revised minutes of the BAC meeting of 28 June 1968. HSBC, Chairman's Papers, BAC, 1968.

${ }^{64}$ These included Chase Manhattan Bank in Aberdeen, Prince’s Building and North Point, Banque de l'Indochine in Western district, Wanchai-Causeway Bay and Midlevels area. Minutes of the BAC, 28 June 1968. HSBC, Chairman’s Papers, BAC 1968.

${ }^{65}$ Circular letter to all banks, 27 January 1969 from Leo Cole. HSBC, Chairman’s Papers, BAC 1969.

${ }^{66}$ Cole to Curran (Deputy chief manager HSBC), 14 February 1969. HSBC, Chairman's Papers, BAC, 1969.

${ }^{67}$ On the detail of the bank failures of 1982-1986 see Jao, 'Recent Banking Crises in Hong Kong and Taiwan’ and Ghose, Banking System of Hong Kong, pp. 82-96. 